\title{
Influence of metal turning assisted with high density current pulses on surface hardness in an AISI/SAE 1045 steel
}

\author{
Influencia del torneado de metales asistido por pulsos de corriente de alta \\ densidad sobre la dureza superficial de un acero AISI/SAE 1045
}

\author{
C. A. Montilla-Montaña iD ;J. S. Jaramillo-Blandón iD ; A. F. Rodríguez-Valencia
}

\begin{abstract}
Resumen -Dentro de la familia de procesos de conformado asistidos eléctricamente (Electrically Assisted Forming) EAF, el proceso híbrido de torneado asistido in situ con electropulsos, viene siendo estudiado para determinar la influencia de electropulsos en la potencia de mecanizado, acabado superficial y macrodureza. Aplicando técnicas de DOE, el presente trabajo de investigación se centra en estudiar como respuesta la macrodureza en un acero AISI/SAE 1045 sometido a un proceso de torneado asistido eléctricamente, considerando diferentes factores. Los resultados obtenidos a partir del análisis de varianza ANOVA, muestran que la velocidad de avance tiene influencia sobre la dureza superficial del material. Así mismo, la interacción entre los factores frecuencia de pulsos y ancho de pulso del proceso de torneado asistido eléctricamente, evidencia un impacto en la dureza superficial del acero AISI/SAE 1045. Se aborda también la interacción tiple entre velocidad de avance, frecuencia de pulsos y ancho de pulso, y su incidencia en la característica de respuesta bajo estudio.
\end{abstract}

Palabras claves - diseño de experimentos, electroplasticidad, pulsos de corriente de alta densidad, torneado de metales.

Abstract - Within the family of electrically assisted forming processes EAF, the hybrid process of turning assisted in-situ with electropulses, is being studied to determine the influence of electropulses on machining power, surface finish and macro hardness. Applying DOE techniques, the present research work focuses on studying the response of macro hardness in an AISI / SAE 1045 steel under an electrically assisted turning process, considering different factors. The results obtained from the Analysis of Variance ANOVA show that the feed has an influence on the surface hardness of the material. Likewise, the interaction between the factors pulse frequency and pulse width of the electrically assisted turning process shows an impact on the

This manuscript was sent on December 06, 2018 and accepted on May 16, 2019. This work was supported in part by the Universidad Tecnológica de Pereira, under project investigation "Desarrollo de una metodología para tornear piezas con la asistencia de pulsos de alta densidad de corriente E6 14 18 ".

C. A. Montilla-Montaña., is with Facultad de Tecnología of Universidad Tecnológica de Pereira, Colombia. (cmontilla@utp.edu.co) surface hardness of AISI / SAE 1045 steel. The triple interaction between feed, pulse frequency and pulse width, and its incidence on the response characteristic under study is also addressed.

Index Terms - design of experiments DOE, electroplasticity, electropulse, metal turning.

\section{INTRODUCTION}

$\mathrm{D}$ ESIGN of experiments (DOE) can be defined as a methodology based on mathematical and statistical tools which objective is to help the experimenter to:

- Select the optimal experimental strategy that allows to obtain the required information with the minimum cost.

- Evaluate the obtained experimental results, assuring maximum reliability in the obtained conclusions [1].

Statistical design of experiments can be applied on numerous situations whose objective is to obtain quality information, which is the base for the development of new products and processes, understanding a system and take decision to optimize and improve its quality. DOE methodology can be applied to MIMO systems (Fig. 1), in which one or more dependent variables or outputs depend on the values of one or more independent controllable variables $(\mathrm{x})$ called factors. Outputs can be influenced by other variables that are not controlled by the experimenter.

J. S. Jaramillo-Blandón is an Mechanical Engineering master Student, in Universidad Tecnológica de Pereira, Colombia. (jsjaramillo@utp.edu.co)

A. F. Rodríguez-Valencia., is with Facultad de Mechanical Engineering of Universidad Tecnológica de Pereira, Colombia. (andrefeliprodriguez@utp.edu.co) 


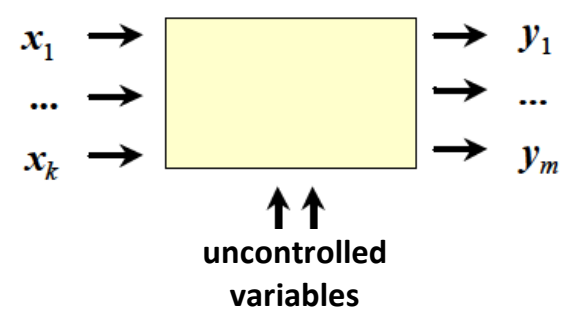

Fig. 1. Depiction of a studied system showing the factors (x) and the outputs (y) [1].

The research work hereby presented focuses in the process of electropulses assisted turning (application of electroplasticity), where the machining parameters such as cutting speed, feed, cutting depth, constitute the system inputs and the output corresponds to material hardness.

Electroplasticity is the effect produced on the plastic flow of materials due to the application of high density electrical current pulses, with magnitudes of around $15 \mathrm{~A} / \mathrm{mm}^{2}$ for $60 \mu \mathrm{s}$ periods. DC high density current, when applied in short duration pulses, can significantly improve the rate of plastic deformation in metals, in addition to the Joule effect. Sprecher and others [2] and Troitskii [3, 4] have found that some of the effects of the application of high density current pulses in metal work are:

- Reduction in the required force for metal work.

- Reduction in fragility.

- Improvement of surface roughness.

- Changes in texture.

One of the beneficial effects of electroplasticity on metals is the reduction of yield strength [5], which could allow to take advantage of this kind of effect to work on certain metals or alloys that are very difficult to process with conventional machining, or in the case of common materials increase productivity, with the subsequent economic benefits.

The application of electroplasticity in metal work is relatively new and according to some authors who have worked on the subject [6-9], it is an efficient process in terms of energy consumption and environmentally friendly.

Fundamentally, electropulse assisted turning belongs to the family of Electrically Assisted Forming (EAF) [10], in which, while a piece is mechanically stressed, a high-density current train pulse is circulated through the piece-tool set.

Metal turning assisted with high density current pulses has been investigated since the year 2012 [11, 12], in a collaborative work between teachers of the Universidad Politécnica de Cataluña (Spain) and the Universidad Tecnológica de Pereira UTP. Results of these studies have shown benefits in its use, in terms of improvements in surface finish, material machinability and reduction in the consumed machining power [11, 12].

From the point of view of classical metal cutting theory, the necessary power to remove a layer of a material of certain mechanical properties using turning, under a certain cutting regime (angular velocity, feed, depth, lubrication, etc.), is directly proportional to ultimate strength $\sigma_{\mathrm{r}}$ of the material to machine. Based on the proven results of electroplasticity the value of $\sigma_{\mathrm{r}}$ is transiently reduced and material ductility is increased, studies [11] and [12] have confirmed that there is indeed a reduction in the required power for turning assisted with high density current pulses.

\section{OBJECTIVE}

It is desired to assess the change in surface hardness on an AISI/SAE 1045 steel, when turned with the assistance of electropulses. It is unknown which input variables have the greatest impact on hardness, being this the main motivation for the present study.

This research work focuses on applying DOE techniques to perform a pilot test and find the variables with the most influence via a fractional design of the experimental process in which cutting parameters (cutting speed, feed, cutting depth) and current pulses parameters (frequency and pulse width) are given. Then a full $2^{3}$ factorial design is carried out, to which an Analysis of Variance (ANOVA) is applied. Lastly, the variables with the most influence on surface roughness of AISI/SAE 1045 steel after the machining process are evaluated.

\section{METHODOLOGY}

The first factorial experiment presented in this paper corresponds to a fractional factorial design with 5 factors and 2 levels. The factors and their levels are shown on table I, for the pilot test performed. The fractional design is of shape $2^{k-p}$ where $\mathrm{k}=5$ and $\mathrm{p}=2$ (fraction $1 / 4$, resolution III), therefore the number of experimental runs required with 2 generators is 16 in total; surface hardness being the output variable, measured on the different experimental specimens and with the corresponding correction factor for cylindrical surfaces.

TABLE I

FACTORS AND LEVELS OF THE PILOT TEST

\begin{tabular}{lcc}
\hline \multicolumn{1}{c}{ Factors } & \multicolumn{2}{c}{ Levels } \\
\hline Cutting depth $[\mathrm{mm}]$ & 0,81 & 1,27 \\
Pulse frequency $[\mathrm{Hz}]$ & 100 & 300 \\
Pulse width $[\mu \mathrm{s}]$ & 50 & 200 \\
Cutting speed $[\mathrm{m} / \mathrm{min}]$ & 28,3 & 35,9 \\
Feed $[\mathrm{mm} / \mathrm{rev}]$ & 0,138 & 0,174 \\
& & \\
\hline \hline
\end{tabular}

To execute the different experimental tests according to table I, it was required to fabricate cylindrical AISI/SAE 1045 steel specimens, $150 \mathrm{~mm}$ long and with a $12,7 \mathrm{~mm}\left({ }^{1} / 2 "\right)$ diameter. The specimens were placed between the chuck and the tailstock in a lathe, using an electrical insulating material in the moment the electropulses were applied. Table 2 shows the chemical composition of the material used in this study.

TABLE II

CHEMICAL COMPOSITION OF THE MATERIAL AISI/SAE 1045 [13]

\begin{tabular}{llllllll}
\hline \hline SAE & \% C & \% Mn & \% Si & \% P & \% S & \% Cr & $\% \mathbf{C u}$ \\
\hline & 0,45 & 0,7 & 0,25 & 0,008 & 0,007 & 0,07 & 0,01 \\
\hline \hline
\end{tabular}


The machining process was carried out in a revolver lathe model TOZ, ZPS-R5, employing a Hard Metal (HM) tool. During the different experimental tests performed in the Machine Tools laboratory of the Universidad Tecnológica de Pereira, the different cutting parameters were programed in the lathe and a current pulses generator was used where the pulse width and frequency were varied. The machining length where the pulses were applied was $80 \mathrm{~mm}$. It is important to also mention that, for each test, electrical insulation had to be verified between the specimen and the chuck and between the cutting tool and the tool holder, using a multimeter to verify the no continuity. Fig. 2 shows the experimental scheme of the electrically assisted turning process.

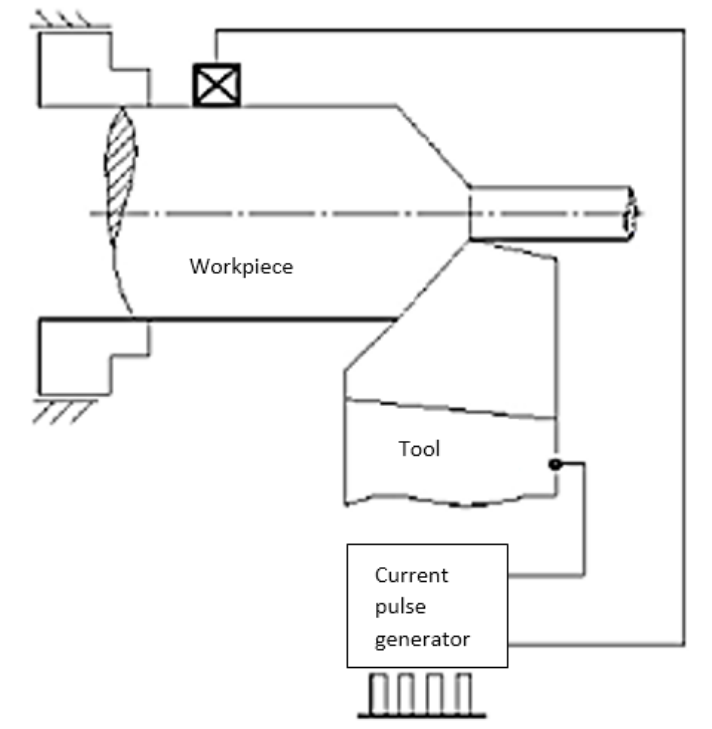

Fig. 2. Experimental scheme of the process of electrically assisted turning

Table III presents the experimental tests performed and the different combinations of levels and factors according to fractional factorial design, which are in random order. Once the specimens were machined, measures of hardness were taken, using an HP-250 hardness tester from the brand Wekstoffprüfmaschinen (Fig. 3).

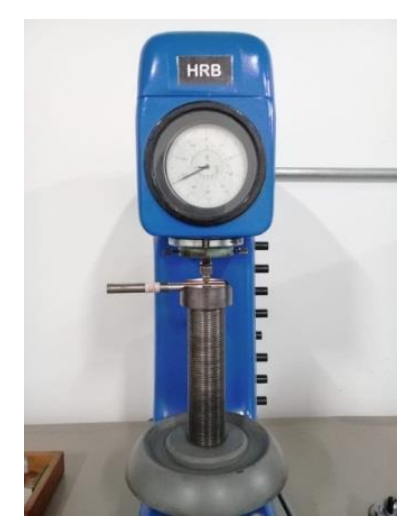

Fig. 3. Hardness tester.

For each specimen 5 hardness measurements were recorded in the Rockwell B scale, on different zones of the machined region. To the obtained values, a correction was applied due to their cylindrical shape, according to the indications from standard ASTM E18-79 [14].

TABLE III.

FRACTIONAL FACTORIAL DESIGN FOR THE ELECTROPULSES MACHINING PROCESS

\begin{tabular}{cccccc}
\hline \hline & & & & \\
& & & & \\
& & & & & \\
\hline 1 & 1,27 & 200 & 300 & 28,33 & 0,2116 \\
2 & 1,27 & 50 & 100 & 28,33 & 0,1354 \\
3 & 1,27 & 200 & 100 & 22,34 & 0,2116 \\
4 & 1,27 & 50 & 300 & 22,34 & 0,1354 \\
5 & 0,81 & 200 & 100 & 28,33 & 0,1354 \\
6 & 0,81 & 50 & 100 & 22,34 & 0,2116 \\
7 & 0,81 & 200 & 300 & 22,34 & 0,1354 \\
8 & 0,81 & 50 & 300 & 28,33 & 0,2116 \\
9 & 1,27 & 200 & 300 & 28,33 & 0,2116 \\
10 & 1,27 & 50 & 300 & 22,34 & 0,1354 \\
11 & 1,27 & 200 & 100 & 22,34 & 0,2116 \\
12 & 1,27 & 50 & 100 & 28,33 & 0,1354 \\
13 & 0,81 & 50 & 300 & 28,33 & 0,2116 \\
14 & 0,81 & 200 & 100 & 28,33 & 0,1354 \\
15 & 0,81 & 50 & 100 & 22,34 & 0,2116 \\
16 & 0,81 & 200 & 300 & 22,34 & 0,1354 \\
& & & & & \\
\hline \hline
\end{tabular}

\section{RESULTS AND DISCUSSION}

The last column of table III presents the different hardness values taken on the different specimens according to the different factors and levels applied to each one. On the Minitab software [15], an Analysis of Variance ANOVA was performed for this $2^{5-2}$ fractional design, which is presented on table IV.

TABLE IV.

ANALYSIS OF VARIANCE FOR THE FRACTIONAL DESIGN [15]

\begin{tabular}{|c|c|c|c|c|}
\hline "Source & $\overline{\mathrm{DF}}$ & Adj SS & Adj MS & F-Value \\
\hline $\begin{array}{l}\text { Cutting depth } \\
\text { [mm] }\end{array}$ & 1 & 1,2741 & 1,2741 & 1,25 \\
\hline WP Error & 2 & 2,0338 & 1,0169 & 0,23 \\
\hline Pulse width $[\mu \mathrm{s}]$ & 1 & 0,1287 & 0,1287 & 0,03 \\
\hline $\begin{array}{l}\text { Pulse frequency } \\
{[\mathrm{Hz}]}\end{array}$ & 1 & 4,3420 & 4,3420 & 0,98 \\
\hline $\begin{array}{l}\text { Cutting speed } \\
{[\mathrm{m} / \mathrm{min}]}\end{array}$ & 1 & 2,3218 & 2,3218 & 0,53 \\
\hline Feed $[\mathrm{mm} / \mathrm{rev}]$ & 1 & 6,5472 & 6,5472 & 1,48 \\
\hline $\begin{array}{l}\text { Cutting depth } \\
{[\mathrm{mm}]^{*} \text { Pulse }} \\
\text { frequency }[\mathrm{Hz}]\end{array}$ & 1 & 3,8661 & 3,8661 & 0,88 \\
\hline $\begin{array}{l}\text { Pulse width } \\
{[\mu \mathrm{s}]^{*} \text { Pulse }} \\
\text { frequency }[\mathrm{Hz}]\end{array}$ & 1 & 25,9718 & 25,971 & 5,89 \\
\hline SP Error & 6 & 26,4708 & 4,4118 & \\
\hline Total & 15 & & & \\
\hline Source & & P-Value & & \\
\hline Cutting depth [mm & & 0,379 & & \\
\hline WP Error & & 0,801 & & \\
\hline Pulse width $[\mu \mathrm{s}]$ & & 0,870 & & \\
\hline
\end{tabular}




\begin{tabular}{ll} 
Pulse frequency $[\mathrm{Hz}]$ & 0,359 \\
Cutting speed $[\mathrm{m} / \mathrm{min}]$ & 0,495 \\
Feed $[\mathrm{mm} / \mathrm{rev}]$ & 0,269 \\
$\begin{array}{l}\text { Cutting depth } \\
{[\mathrm{mm}] * \text { Pulse frequency }}\end{array}$ & 0,385 \\
{$[\mathrm{~Hz}]$} & \\
$\begin{array}{l}\text { Pulse width }[\mu \mathrm{s}] * \text { Pulse } \\
\text { frequency }[\mathrm{Hz}]\end{array}$ & 0,051 \\
$\begin{array}{l}\text { SP Error } \\
\text { Total }\end{array}$ \\
\hline
\end{tabular}

According to the analysis of Variance the double interaction pulse width and pulse frequency presents a $\mathrm{p}$-Value of 0,05 which indicate that these variables have influence on the studied response, which is surface hardness; besides, though it doesn't have such a significant influence, the variable that presents a $\mathrm{p}$ Value closest to 0,05 is the feed, which is why these 3 variables are selected to later perform the full factorial design. Fig. 4 presents the Pareto chart where the variables with more influence can be seen more clearly.

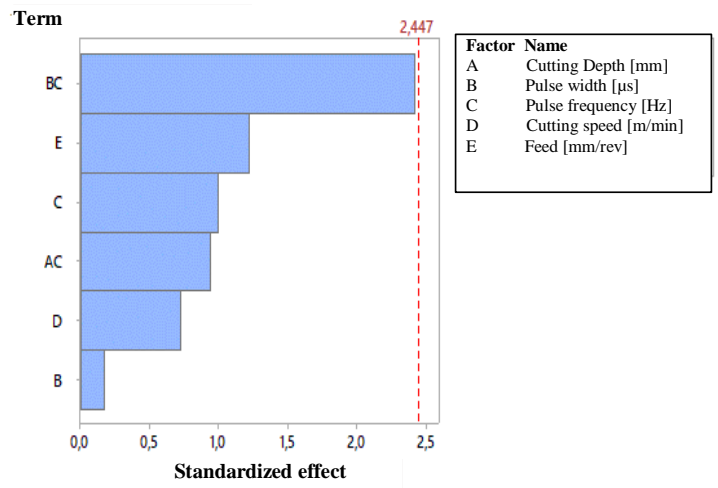

Fig. 4. Pareto chart of standardized effects [15].

The analysis of residuals (fig. 5) is important to analyze the behavior of the data. The normal probability plot indicates that some of the data are centered around zero and follow the fit line.

The frequency histogram shows that, although most of the data are not centered around zero, they tend to show the behavior of a normal distribution. On the other hand, the plot of standardized residuals versus the order of observation of the data follows an irregular curve, which indicates that there is randomness in the data collection.

According to the previously obtained results, a full factorial design is performed for the variables that have more influence on the response; in this analysis pulse frequency, pulse width and feed are included. The selected variables concur with studies done by Sánchez et al. [12], in which the material surface hardness is influenced by the rate of plastic deformation, which in turn is related to the feed.

According to Sánchez et al. [11, 12], the greatest reductions in hardness on AISI/SAE 1045 carbon steel and AISI/SAE 4140 steel were observed for frequencies from $100 \mathrm{~Hz}$ to $300 \mathrm{~Hz}$, feeds of $0,046 \mathrm{~mm} / \mathrm{rev}$ and pulse durations of $200 \mu \mathrm{s}$. Table V shows the variables pulse width, pulse frequency and feed, the combinations of their different levels and the new hardness results from the new turned specimens.
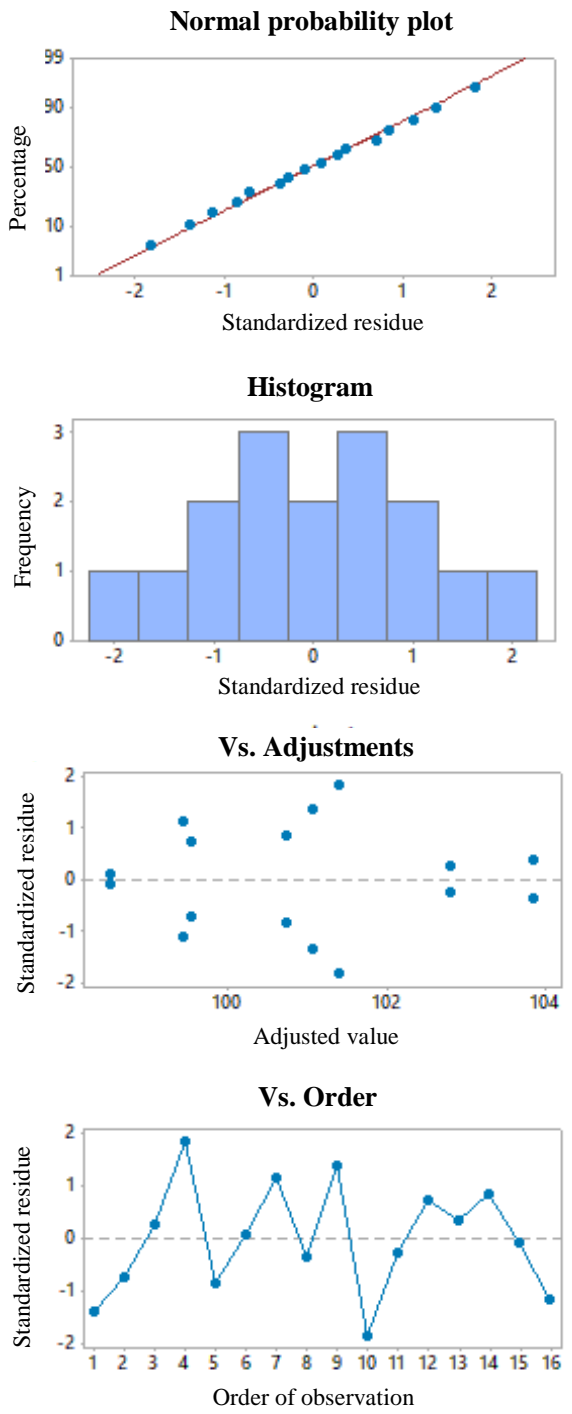

Fig. 5. Residuals plots for hardness HRB [15].

TABLE V.

COMBINATIONS OF LEVELS FOR THE $2^{3}$ FACTORIAL DESIGN WITH THEIR RESPECTIVE HARDNESS VALUES

\begin{tabular}{|c|c|c|c|c|c|}
\hline 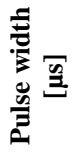 & 兽总胥 & 总 & 总 & 苞 & 总总 \\
\hline 50 & 300 & 0,138 & 100,75 & 2,50 & 103,25 \\
\hline 50 & 300 & 0,174 & 100,85 & 2,50 & 103,35 \\
\hline 50 & 100 & 0,138 & 98,40 & 2,58 & 100,98 \\
\hline 200 & 100 & 0,174 & 100,15 & 2,50 & 102,65 \\
\hline 50 & 100 & 0,174 & 96,35 & 2,68 & 99,03 \\
\hline 50 & 100 & 0,138 & 95,40 & 2,73 & 98,13 \\
\hline 50 & 300 & 0,174 & 102,10 & 2,50 & 104,60 \\
\hline 200 & 300 & 0,174 & 96,10 & 2,69 & 98,79 \\
\hline
\end{tabular}




\begin{tabular}{cccccc}
50 & 100 & 0,138 & 98,95 & 2,55 & 101,50 \\
200 & 100 & 0,138 & 97,40 & 2,63 & 100,03 \\
50 & 300 & 0,138 & 96,80 & 2,66 & 99,46 \\
200 & 100 & 0,138 & 95,85 & 2,70 & 98,55 \\
50 & 300 & 0,174 & 101,30 & 2,50 & 103,80 \\
50 & 100 & 0,174 & 97,75 & 2,61 & 100,36 \\
200 & 100 & 0,138 & 99,60 & 2,52 & 102,12 \\
200 & 300 & 0,138 & 95,50 & 2,72 & 98,22 \\
50 & 100 & 0,174 & 96,00 & 2,70 & 98,70 \\
200 & 100 & 0,174 & 100,45 & 2,50 & 102,95 \\
200 & 300 & 0,174 & 100,85 & 2,50 & 103,35 \\
50 & 300 & 0,138 & 96,90 & 2,65 & 99,55 \\
200 & 300 & 0,138 & 99,80 & 2,51 & 102,31 \\
200 & 300 & 0,174 & 100,85 & 2,50 & 103,35 \\
200 & 300 & 0,138 & 98,75 & 2,56 & 101,31 \\
200 & 100 & 0,174 & 101,35 & 2,50 & 103,85 \\
& & & & & \\
\hline \hline
\end{tabular}

An Analysis of Variance ANOVA was performed on the data from table $\mathrm{V}$, and the p-Values shown on fig. 6 were obtained. The resulting $\mathrm{p}$-Value of 0,037 indicates that feed has influence on the material surface hardness.

Also, the double interaction of pulse width and pulse frequency causes an impact on the response, since its $\mathrm{p}$-Value is less than 0,05; therefore, the null hypothesis is rejected, and the alternative hypothesis is accepted, which indicates that these factors influence the response. The triple interaction pulse width, pulse frequency and feed has a p-Value of 0,062 , which is close to the limit thus allowing to state that the joint effect of these three factors has influence in the material surface hardness.
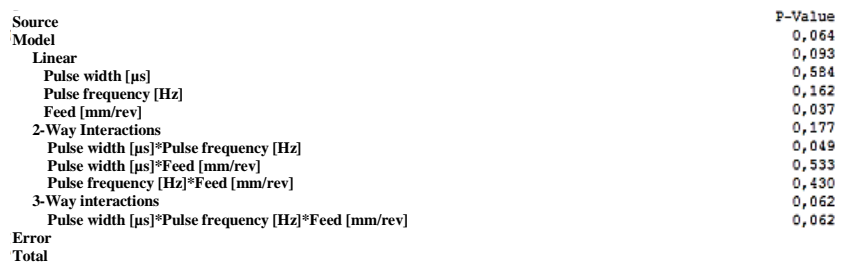

Fig. 6. p-Values for the full $2^{3}$ factorial design [15].

Fig. 7 shows the residual plots for hardness HRB from the full factorial design. In the normal probability plot an approximation of the data to follow the fitting line is evidenced; while the histogram shows that the data are not totally centered around zero, however they show a distribution that tends to be normal. Once again it can be seen that there are no patterns in the order of the data collection and therefore there is randomness in them.

An Analysis of Variance ANOVA is shown on table VI for the full $2^{3}$ factorial design. It can be seen how we have 7 effects, out of which 3 are main effects, 3 are double interactions and one triple interaction. For each of them the degrees of freedom, the sum of squares, mean squares and test statistics have been determined.
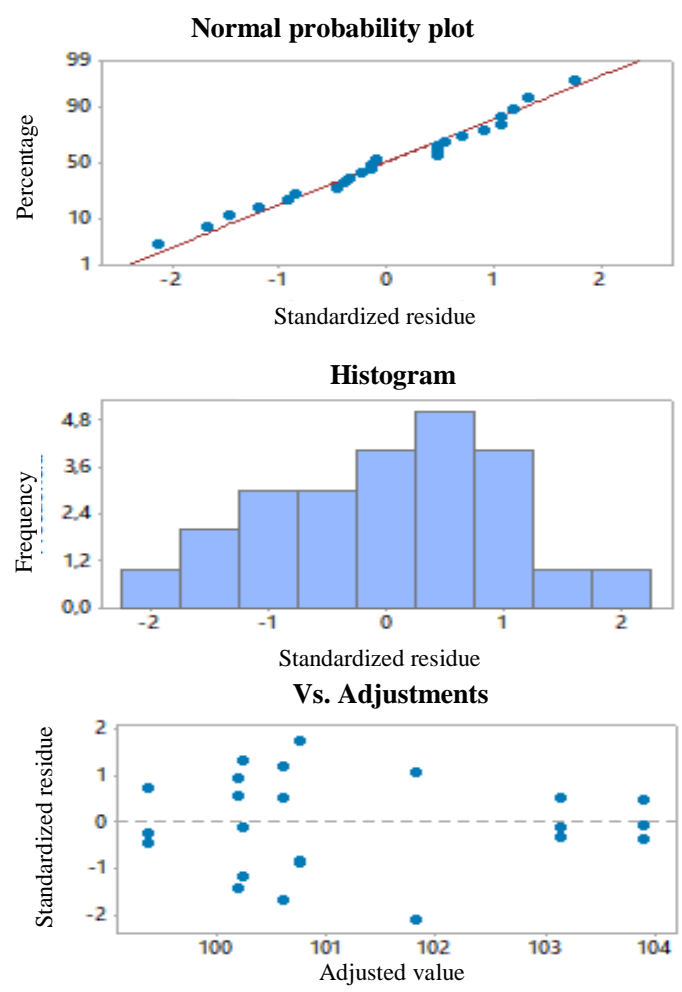

Vs. Order

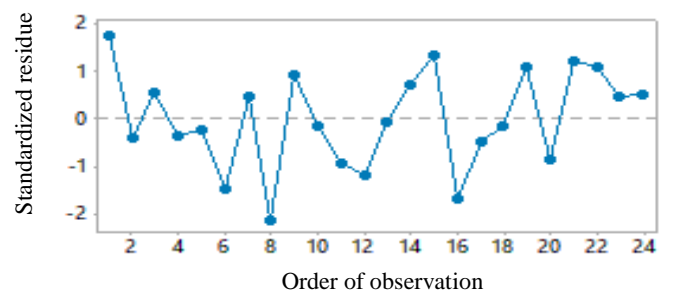

Fig. 7. Residual plots for hardness HRB in full factorial design [15].

Test statistics (F Value) allow us to also determine what variables have influence on the response, being an alternate method to comparing $\mathrm{p}-$ Values with the significance of 0,05 . On this method, yet again, feed and the double interaction pulse width with pulse frequency are the ones that have a greater effect on the response.

TABLE VI.

COMBINATIONS OF LEVELS FOR THE $2^{3}$ FACTORIAL DESIGN WITH THEIR RESPECTIVE HARDNESS VALUES [15]

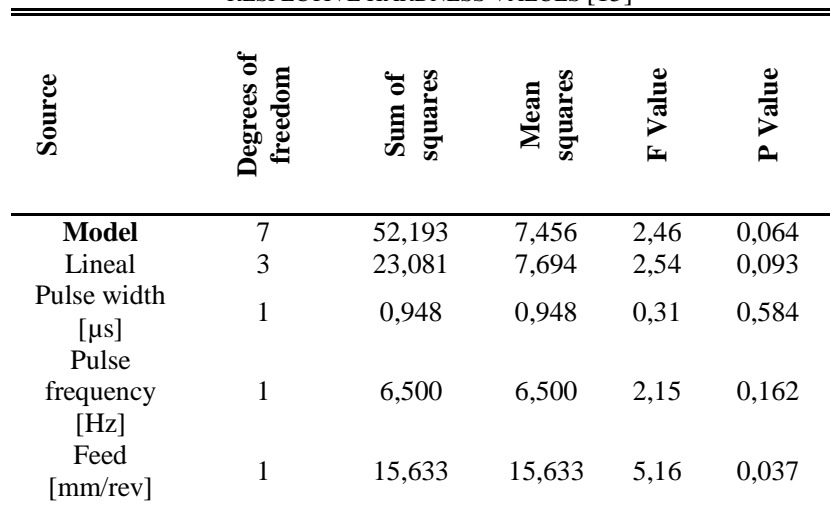




\begin{tabular}{cccccc}
$\begin{array}{c}\text { Double } \\
\text { interactions } \\
\quad \text { Pulse }\end{array}$ & 3 & 16,914 & 5,638 & 1,86 & 0,177 \\
$\begin{array}{c}\text { width*Pulse } \\
\text { frequency } \\
\quad \text { Pulse }\end{array}$ & 1 & 13,696 & 13,696 & 4,52 & 0,049 \\
$\begin{array}{c}\text { width*Feed } \\
\quad \text { Pulse } \\
\text { frequency*F } \\
\quad \text { eed }\end{array}$ & 1 & 1,229 & 1,228 & 0,41 & 0,533 \\
$\quad 1$ & 1,990 & 1,989 & 0,66 & 0,430 \\
$\begin{array}{c}\text { Triple } \\
\text { Interactions } \\
\quad \text { Pulse }\end{array}$ & 1 & 12,198 & 12,198 & 4,03 & 0,062 \\
$\begin{array}{c}\text { width*Pulse } \\
\text { frequency*F } \\
\text { eed }\end{array}$ & 1 & 12,198 & 12,198 & 4,03 & 0,062 \\
$\quad$ Error & 16 & 48,452 & 3,028 & & \\
$\quad$ Total & 23 & 100,645 & & & \\
\hline \hline
\end{tabular}

In fig. 8 it can be appreciated that feed corresponds to the straight line with the greatest slope, which matches with the obtained p-Value of 0,037 ; in comparison with the values of pulse width and pulse frequency, with p-Values of 0,584 and 0,162 respectively, therefore, it is the feed the one that has influence on the obtained surface hardness.

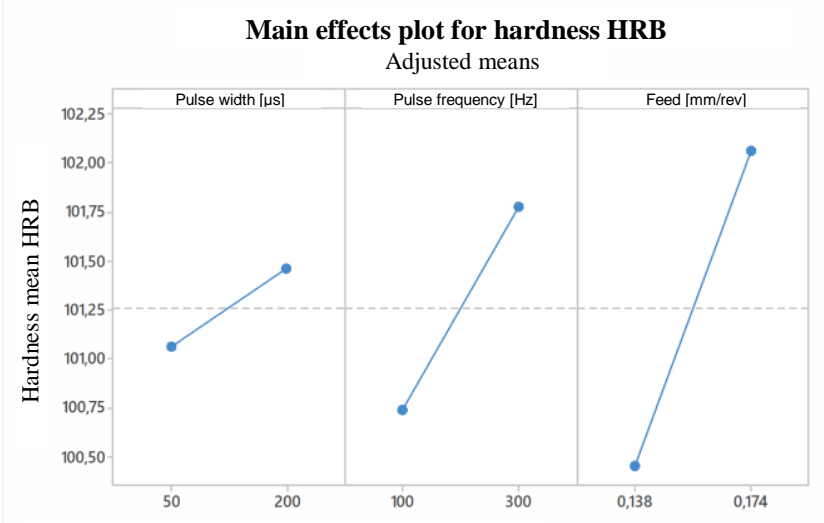

All terms shown are in the model.

Fig. 8. Main effects plot [15].

Table VII shows the values of the lineal regression presenting the standard deviation and the coefficient of determination $\left(R^{2}\right)$.

TABLE VII.

STANDARD DEVIATION AND COEFFICIENT OF DETERMINATION [15].

\begin{tabular}{cccc}
\hline \hline Model summary & & & \\
\hline \hline $\begin{array}{c}\text { Standard } \\
\text { deviation S }\end{array}$ & $\mathbf{R}^{2}$ & $\mathbf{R}^{2}$ adjusted & $\mathbf{R}^{2}$ predicted \\
\hline 1,9693 & $22,33 \%$ & $11,37 \%$ & $0 \%$ \\
\hline \hline
\end{tabular}

It is important to note that, considering the three variables feed, pulse width and pulse frequency with hardness as the response, they present a low coefficient of determination with a value of $22,33 \%$ therefore it doesn't fit well to a linear model where all three variables are considered. The experimental process may require a different model and an experimental volume bigger than the one proposed, something that is beyond the reach of the study here performed.

In the case of hardness HRB and feed, they don't have a linear relationship. This is confirmed in the study performed by Sánchez et al. [11], that shows the relative hardness of AISI/SAE 1020, 1045 and 4140 steels under an assisted turning process with electropulses at $100 \mathrm{~Hz}$ and pulse duration of 200 $\mu \mathrm{s}$ and $50 \mu \mathrm{s}$, and the relative hardness of the same materials when assisted with electropulses at $300 \mathrm{~Hz}$ and a pulse duration of $200 \mu \mathrm{s}$ and $50 \mu \mathrm{s}$. It can be seen how for AISI/SAE 1045 steel hardness doesn't increase as feed is increased.

\section{CONCLUSIONS}

A study has been performed to determine the variation on macrohardness of an AISI/SAE 1045 steel on a turning process assisted with electropulses. Based on DOE techniques a $2^{5-2}$ fractional factorial design was performed as a pilot test including the factors cutting depth, cutting speed, feed, pulse width and pulse frequency. The results allowed to discard the factors cutting speed and cutting depth, since statistically they didn't have significant influence on the response.

A full $2^{3}$ factorial design was carried out involving the factors feed, pulse frequency and pulse width, for which an Analysis of Variance, main effects plot and residual plot were performed.

The feed was the factor that, independently, had the most influence on the material surface hardness, with a $p$-Value of 0,037 ; which is below the level of significance used of 0,05 .

The interaction between the factors pulse frequency and pulse width of the electrically assisted turning process show an impact on surface hardness for AISI/SAE 1045 steel. However, it isn't possible to make a conclusive statement regarding this subject without performing additional tests and research involving pulse frequencies and widths with different levels, since the obtained $\mathrm{p}$-Value for the interaction of these two factors is very close to the significance value of 0,05 .

The triple interaction of pulse frequency, pulse width and feed doesn't produce a significant effect in the variation of surface hardness, since its $\mathrm{p}$-Value is 0,062 ; besides, it corroborates the results of studies performed previously for 1045 steel, where there isn't a significant variation in hardness for feeds between $0,046 \mathrm{~mm} / \mathrm{rev}$ and $0,356 \mathrm{~mm} / \mathrm{rev}$, pulse width of $200 \mu \mathrm{s}$ and frequency of $300 \mathrm{~Hz}$.

\section{REFERENCES}

[1] Ferré, J. Rius, X. Introducción al diseño estadístico de experimentos. Técnicas de laboratorio, vol. 24, n 24, pp. 648-663, septiembre de 2002.

[2] Sprecher, A.F., Mannan S.L., Conrad, H. On the mechanisms for the electroplastic effect in metals. Acta Metall, Vol . 34, No. 7, pp. 1145-1162, 1986. DOI: 10.1016/0001-6160(86)90001-5

[3] Troitskii, O.A. Electromechanical effect in metals. Institute of solid state physics, USSR. Academy of sciences. 1969.

[4] Troitskii, O.A. The Electroplastic effects in metals. Institute of Physical Chemistry, Academy of Sciences of the USSR, Moscow. 
Translated from Problemy Prochnosti, No. 2, pp. 103-106, Febreuary, 1984.

[5] Montilla, C. Higuera, Ó. Kallewaard, V. González, H. Sánchez, A. Electropulsing effects on mechanical and metallurgical behavior of AISI-SAE 4140 steel. Contemporary Engineering Sciences, Vol. 11, 2018, no. 59, $2911 \quad-\quad 2921.2018$. https://doi.org/10.12988/ces.2018.86297.

[6] Conrad, Hans. Electroplasticity in metals and ceramics. Materials science and Engineering. A 287 (2000), 276 - 287. DOI: 10.1016/S0921-5093(00)00786-3

[7] LI, Dalong, YU, Enlin. Computation Method of metals flow stress for electroplastic effect. Materials Science and Engineering A 505 (2009) pp. 62-64. DOI: 10.1016/j.msea.2008.10.040

[8] Tang, G. Experimental study of electroplastic effect on stainless steel wire 304L. Materials Science and Engineering A281 (2000) 263-267. DOI: 10.1016/S0921-5093(99)00708-X

[9] Tao Jia, Shih Albert J., Ni Jun. Experimental Study of the Dry and Near-Dry Electrical Discharge Milling Processes. Journal of Manufacturing Science and Engineering, february 2008, Vol. 130 / 011002-1 DOI:10.1115/1.2784276

[10] Salandro W, Jones J, Bunget C, et al. Electrically Assisted Forming. 1a edición. Switzerland: Springer International Publishing, 2015. 355p. ISBN: 978-3-319-08878-5. DOI: 10.1007/978-3- 319-088792.

[11] Sánchez, A.; González, H.; Montilla, C.; Kallewaard, V. Manufacturing improves when turning process is assisted in situ by short time electropulsing. Journal of Materials Processing Technology, 222: 327-334. 2015. DOI: 10.1016/j.\%20proeng.2015.12.526

[12] Sánchez, A.; González, H.; Montilla, C.; Kallewaard, V. (2015b) Turning process assisted in situ by short time current pulses. In Proceedings Engineering of Manufacturing Engineering Society International Conference MESIC 2015, Barcelona (Spain). 10.1016/j.proeng.2015.12.526. Available on: www.elsevier.com/locate/procedia.

[13] Compañía general de aceros. SAE 1020 y SAE 1045. Aceros de ingeniería al carbono. 2007. Catálogo en línea disponible en: http://repository.unilibre.edu.

co/bitstream/handle/10901/7826/VasquezTorresEdwinLibardo2013 Anexos. pdf?sequence $=2$.

[14] Norma ASTM E18-79 Método estándar para la dureza Rockwell de materiales metálicos.

[15] Minitab Software 18. Available on: http://www.minitab.com

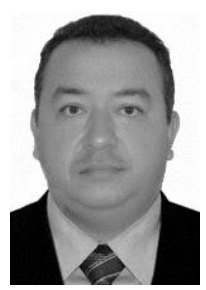

Carlos Alberto Montilla Montaña (d. of b. May 7, 1971). Performed undergraduate studies in Mechanical Engineering (1994) in the Universidad Tecnológica de Pereira (UTP). Worked in the industrial sector for a period of 7 years, and later performed 2 years as an independent worker.

Finished his master studies in automatic systems of production (2006) in the UTP and is currently developing his doctoral thesis.
From the year 2006 he works as faculty teacher in the Technology faculty, Mechanics Technology program of the UTP, in the manufacturing processes area and has guided around 50 degree works.

He has been author of 2 text books and has published papers on indexed journals, both national and international.

Belongs to the research group Manufacture Processes and Machine design and has been researcher and co-researcher in several projects.

ORCID: http://orcid.org/0000-0002-4603-4455

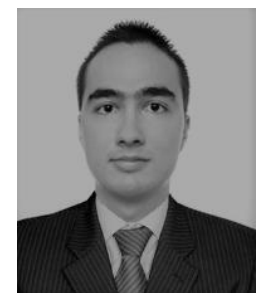

Jeison Steven Jaramillo Blandón was born july 19, 1994 in Pereira (Colombia). Performed his undergraduate studies in Mechatronics Engineering (2017) in the Universidad Tecnológica de Pereira (UTP). He is a student of the master's in mechanical engineering in the study line of design and manufacturing processes in the same university from the year 2017 and in turn performs as an independent worker.

ORCID: http://orcid.org/0000-0002-9287-9918

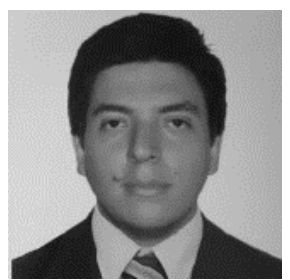

Andrés Felipe Rodríguez Valencia was born September 14, 1992, in La Victoria, Valle (Colombia). Performed his undergraduate studies in Mechanical Engineering (2010-2016) in the Universidad Tecnológica de Pereira (UTP). During his studies he was academical monitor of the mathematics department and monitor of the fluids and hydraulic machines laboratory. On a professional level, he worked in the maintenance section in the Trapiche Biobando S.A.S. company, where he supported the assembly activities, in the area of extraction and production. Worked in Accedo Colombia S.A.S in the commercial sales section of the company. In 2017, began working as teacher in the faculty of Mechanical Engineering, has guided the courses of statics, fluids laboratory and linear algebra. He is a student in the Master of Mechanical Engineering in the study line of design and manufacturing processes of the same university since 2017.

ORCID: http://orcid.org/0000-0002-0540-8019 